\title{
FIRST RECORD OF MEROPLIUS FUKUHARAI (IWASA 1984) (DIPTERA: SEPSIDAE) ON ROMANIAN TERRITORY
}

\author{
LAVINIA IANCU, CRISTINA PURCAREA
}

\begin{abstract}
The present study represents the first report on the presence of Meroplius fukuharai (Diptera: Sepsidae) in Romania. The research area was located in Bucharest. Meroplius fukuharai was recorded during an experiment for investigating necrophagous insect species dynamics. Adult specimens were sampled during the summer (August 2013) from swine carcasses at the beginning of the advanced decay stage. The species had a sporadic occurrence, only four male specimens being sampled and identified both morphologically and genetically during the four-month survey. The recorded environmental parameters during the sampling period showed an air temperature of $28-33^{\circ} \mathrm{C}$ and a relative humidity of $53-57 \%$. This report on the presence of M. fukuharai in Romania leads to the expansion of its known distribution range in the South Eastern part of Europe.
\end{abstract}

Résumé. Ce travail représente le premier rapport sur la présence de Meroplius fukuharai (Diptera: Sepsidae) en Roumanie. La zone de recherche a été située à Bucarest. Meroplius fukuharai a été enregistré pendant une étude sur la dynamique des espèces d'insectes nécrophages. Les adultes ont été échantillonnés pendant l'été (août 2013) sur des carcasses de porc au début de la phase de décomposition avancée. L'espèce a eu une présence sporadique, seulement quatre spécimens mâles étant échantillonnés et identifiés, à la fois en utilisant des caractères morphologiques et génétique, pendant les quatre mois d'étude. Les paramètres environnementaux enregistrés au cours de la période d'échantillonnage ont montré une température de l'air de $28-33^{\circ} \mathrm{C}$ et une humidité relative de $53-57 \%$. La présence de $M$. fukuharai en Roumanie signifie une expansion de sa distribution dans la partie de Sud-Est de l'Europe.

Key words: Sepsidae, Meroplius fukuharai, new record, Romania.

\section{INTRODUCTION}

The Sepsidae family comprises the most common species in Europe (Pont \& Meier, 2002). Their dispersion is mainly due to the movement or transportation of livestock, and not the least due to human commercial activities (Pont \& Meier, op. cit.). Meroplius fukuharai was described by Iwasa (1984), from Mori, Oshima (Japan: Hokkaido I.) (Ozerov, 2005). It was first identified in East Asia (1984), followed by Central, Eastern and Western Europe, seeming that this species is expanding its range according to Pont \& Meier (op. cit.).

The European distribution of $M$. fukuharai covered six countries: Great Britain (Ozerov, 1999), France (Gallis, 1994), Germany (Meier, 1999), Czech Republic (Zuska \& Barták, 1997), Hungary ("Fauna Europaea", Version 2.6.2, de Jong, 2013) and Slovakia (Ozerov, 2005), having occasionally occurrence starting from May to September. The Palaearctic distribution of this species extended to Russia, from Moscow and North Ossetia to the Far East province (Amurskaya Oblast', Khabarovskiy Kray, Krasnoyarskiy Kray, Primorskiy Kray, Sakhalinskaya Oblast', Sverdlovskaya Oblast', Tyumenskaya Oblast', Alania, Moskovskaya Oblast') (Ozerov, 1989; 1991; 1999), South Korea (Iwasa 1994; Suh \& Kwon, 1994), Northeast China (Manchuria; Iwasa, 1995) and Japan (Hokkaido, Honshu, Kyushu) (Iwasa, 1995). Fauna Europaea (Version 2.6.2, de Jong, 2013) cites the presence of this species also in Asian Turkey, Caucasian Russian republics, Georgia, Armenia, Azerbaidjan, Lebanon, Syria, Israel, Jordan, Sinai Peninsula (Egypt), Arabian Peninsula, Iran and Iraq. 
The present study extended the reported distribution range of M. fukuharai to South Eastern part of Europe, while recording its incidence in the southern part of Romania (Bucharest). The species was sampled from decomposed swine carcasses exposed in this urban location, during warm season.

\section{MATERIAL AND METHODS}

\section{Experimental design}

M. fukuharai was sampled and identified from swine carcasses at the beginning of advanced decay stage, corresponding to week 6 of a four-month experiment. The carcasses were mounted for forensic investigation purposes in an urban outdoor space located in Bucharest, and protected by $50 \mathrm{~cm} \times 100 \mathrm{~cm}$ metal cages. This experimentation area $\left(44^{\circ} 27^{\prime} 10^{\prime \prime} \mathrm{N}, 2^{\circ} 05^{\prime} 04^{\prime} \mathrm{E}\right)$ has a continental temperate climate and the vegetation near the carcasses was specific for the warm season (Aesculus hyppocastanum, Tilia sp., Fraxinus sp.). The insect occurrence was monitored daily throughout the entire experiment and the environmental parameters were recorded with a thermo-hygrometer P 330 HVAC (Dostmann Electronic) every four hours from $8^{00}$ to $20^{00}$ during day time.

\section{Taxonomic and genetic identification}

Taxonomic identification was performed using the keys provided by Pont \& Meier (2002), with a stereomicroscope Stemi2000 (Zeiss).

For the genetic identification, two specimens of $M$. fukuharai were used. The total genomic DNA was extracted according to DNeasy Blood \& Tissue Kit (Qiagen) protocol. An additional step was introduced at the beginning of the protocol (cellular disruption with beads). The specimens suspended in $200 \mu \mathrm{l} \mathrm{TE}$ with 5 Zirconia Beads II per tub (Invitek), were subjected to continuous $50 \mathrm{~Hz}$ - power for 12 minutes at $20^{\circ} \mathrm{C}$ using a Cell Homogenizer SpeedMill PLUS (Analitik Jena). Further, the DNA purity and concentration were measured with a NanoDrop1000 (Thermo Scientific).

PCR amplification of the partial COI gene sequence was performed using a Mastercycler ProS System (Eppendorf), in a total volume of $50 \mu$ l. The primers used in the reaction were of 10 pmols each (forward LCO1490: 5'-GGTCAACAAATCATAAAGATATTGG-3' and reverse HC02198: 5'-TAAACTTCAGGGTGACCAAAAAATCA-3') (Folmer et al., 1994). The other components consisted in 200 ng insect genomic DNA, 1 unit of Taq DNA polymerase (Thermo Scientific), 1× Taq buffer (Thermo Scientific), 2.5 $\mathrm{mM} \mathrm{MgCl} 2,0.1 \mathrm{mM}$ dNTP (Thermo Scientific). The amplification reaction started with an initial incubation step of $1 \mathrm{~min}$ at $94^{\circ} \mathrm{C}$, followed by 5 cycles of $30 \mathrm{~s}$ at $94^{\circ} \mathrm{C}$ (denaturation), $1.5 \mathrm{~min}$ at $45^{\circ} \mathrm{C}$ (annealing) and $1 \mathrm{~min}$ at $72^{\circ} \mathrm{C}$ (extension), followed by 35 cycles of $30 \mathrm{~s}$ at $94^{\circ} \mathrm{C}, 1.5 \mathrm{~min}$ at $51^{\circ} \mathrm{C}, 1 \mathrm{~min}$ at $72^{\circ} \mathrm{C}$ and a final extension step of $5 \mathrm{~min}$ at $72^{\circ} \mathrm{C}$. The amplified DNA COI gene fragments ( $710 \mathrm{bp}$ ) were analyzed by electrophoresis on $1 \%$ agarose gels, then purified using QIAquick PCR Purification Kit (Qiagen), and sequenced (Macrogen) on both strands.

\section{Sequence analyses}

For species identification the nucleotide sequences of amplicons were processed and analyzed with CodonCode Sequence Assembly and Alignment Software (http:// www.codoncode.com). The sequences were further analyzed using BLAST-NCBI (http://www.ncbi.nlm.nih.gov) screening tool for similarity assignment within nucleotide databases. 
RESULTS

\section{Species occurrence}

Four M. fukuharai male specimens were sampled only once throughout the entire experiment, during the carcasses sixth week of exposure (August 14, 2013). The environmental conditions during the sampling period were $33.01 \pm 1.5^{\circ} \mathrm{C}$ air temperature, $57.0 \pm 6.0 \%$ relative humidity, and $0 \mathrm{~mm}$ precipitation rate. The values represent the average and standard deviation of the recorded parameters for a week period. The occurrence of $M$. fukuharai was rather sporadic. In this respect, the punctual presence of this species during the entire warm period experiment (July 10 - October 10,2013) was a unique observation in this urban setting.

\section{Taxonomic diagnosis}

The taxonomic identification of M. fukuharai was performed using the taxonomic keys provided by Pont \& Meier (2002). Thorax, scutellum and abdomen are dark colored, while the head is partially darkened. The face and generally the parafacial are reddish-yellow. The wings are clear and the halteres yellow. The fore coxa, trochanter, tibia, and femur are yellow, but the last one has the superior part darkened.

The adult males are easily recognized by the simple structure of the fore legs (Fig. 1). The dorsal view of the male hypopygium is illustrated in fig. 1A. The femur does not present anteroventral seta (Fig. 1B), and only the mid tibia presents a ventral seta.
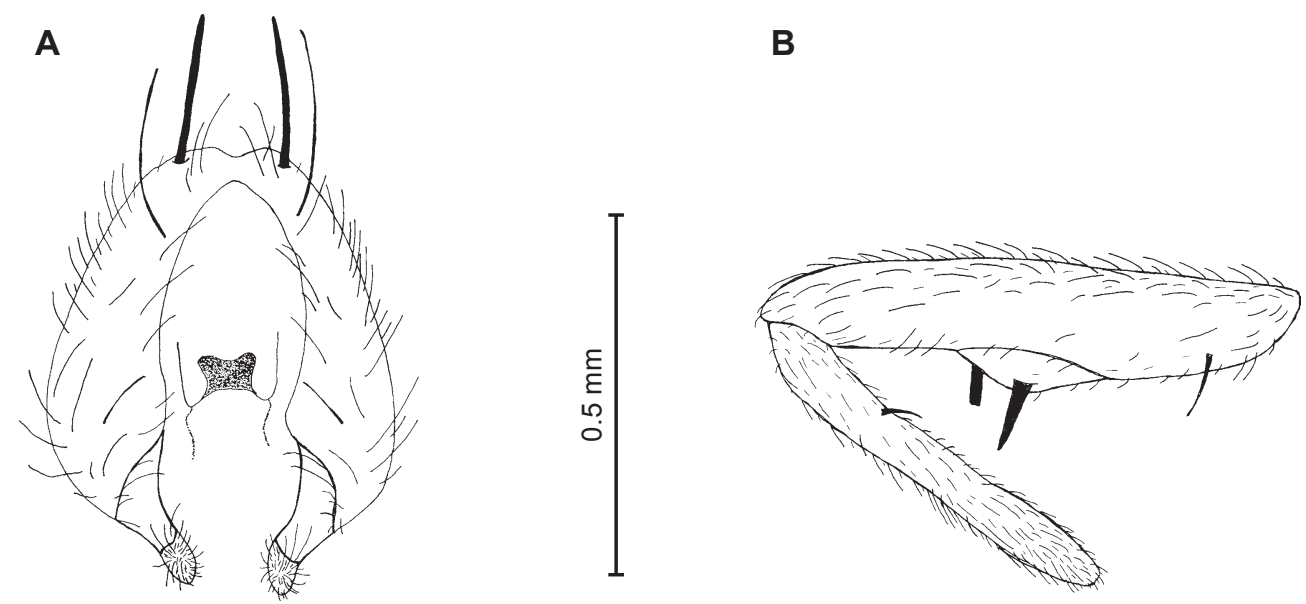

Fig. 1 - Meroplius fukuharai, male: A, hypopygium, dorsal view; B, fore femora, anterior view.

\section{DNA Barcode identification}

The COI (cytochrome oxidase I mitochondrial gene) PCR was performed for two distinct male specimens. The SP1 and SP2 amplicons (710 bp) were sequenced. Their nucleotide sequence analysis using CodonCode Sequence Assembly and 
Alignment Software (http://www.codoncode.com), showed 100\% identity between the two sequences, thus indicating a single species.

SP1 was processed for removing nucleotide sequence errors, and the resulted gene fragment (MF1) of 597-bp was assigned [KP399952] accession number by GenBank.The BLAST analysis of the MF1 closest match revealed 99\% identity with M. fukuharai COI gene fragment [EU435792] over the entire nucleotide sequence.

\section{DISCUSSIONS}

The present study reports the first occurrence of M. fukuharai on Romanian territory. When M. fukuharai was described for the first time by Iwasa (1984), it was specified that this species is often found on swine faeces. Ozerov (1991) sampled adults and larvae from vertebrate carcasses, observations confirmed later by Gallis (1994). Adults were reared under laboratory conditions on chicken and cow excrements, though a change in the development cycle time frame could be observed (Pont \& Meier, 2002). Considering all these previous observations, it is not surprising that in this experiment, the specimens were collected from decomposed swine carcasses. Moreover, it is known that females of this species need to feed for several days on decomposed organic material in order to lay the egg clusters (Pont \& Meier, op. cit.). In accordance with the activity period (May-September), the specimens were sampled and identified in summer - August 2013. Their presence was not observed in May, during similar experimental settings over the cold period (November - May 2013) in the same location (Iancu et al., 2015).

This first report of the presence of M. fukuharai in the Southern part of Romania extends the distribution range of this species into the South Eastern part of Europe.

\section{ACKNOWLEDGEMENTS}

This work was supported for COI gene fragment sequencing, by the Romanian Academy RO1567-IBB05/2013 project of the Institute of Biology Bucharest.

\section{PRIMA SEMNALARE A SPECIEI MEROPLIUS FUKUHARAI (IWASA 1984) (DIPTERA: SEPSIDAE) PE TERITORIUL ROMÂNIEI}

\section{REZUMAT}

Scopul studiului a fost de a raporta pentru prima dată prezența speciei Meroplius fukuharai pe teritoriul României. Zona de cercetare a fost situată în București, România. M. fukuharai a fost înregistrată în timpul unui experiment ce a avut drept obiectiv studiul dinamicii speciilor de insecte necrofage. Exemplarele adulte au fost colectate în timpul verii (august 2013) de pe carcase de porc domestic aflate la începutul stadiului de descompunere avansată. Prezența acestei specii a fost sporadică, fiind colectați și identificați taxonomic și genetic numai patru $\widehat{\partial}$. Parametrii meteorologici înregistrați în timpul perioadei de colectare au arătat o variație a temperaturii aerului de $28-33^{\circ} \mathrm{C}$, și o umiditate cuprinsă între 53 și 57\%. Semnalarea specie M. fukuharai in Romania, duce la extinderea arealului acesteia în partea de sud-est a Europei.

\section{LITERATURE CITED}

DE JONG, Y.S.D.M., 2013 (ed.) - Fauna Europaea version 2.6. Web Service available online at http:// www.faunaeur.org

FOLMER, O., M. BLACK, W. HOEH, R. LUTZ, R. VRIJENHOEK, 1994 - DNA primers for amplification of mitochondrial cytochrome $\mathrm{c}$ oxidase subunit I from diverse metazoan invertebrates. Molecular Marine Biology and Biotechnology, 3: 294-297.

GALLIS, R., 1994 - Xenosepsis fukuharai Iwasa, espèce nouvelle pour la France (Diptera, Sepsidae). Entomologiste, 50 (2): 146. 
IANCU, L., D. O. CARTER, E. N. JUNKINS, C. PURCAREA, 2015 - Using bacterial and necrophagous insect dynamics for post-mortem interval estimation during cold season: Novel case study in Romania. Forensic Science International, 254: 106-117.

IWASA, M., 1984 - Studies on the Sepsidae from Japan (Diptera) III. On the eleven species of eight genera excluding the genera Sepsis Fallén and Themira R.-D., with description of a new species. Kontyû, Tokyo, 52 (2): 296-308.

IWASA, M., 1994 - Two new species of the genus Meroplius Rondani (Diptera, Sepsidae) from the Orientalregion. Japanese Journal of Entomology, 62 (1): 161-166.

IWASA, M., 1995 - Revisional notes on the Japanese Sepsidae (Diptera). Japanese Journal of Entomology, 63 (4): 781-797.

MEIER, R., 1999 - Sepsidae: Pp. 190 In: H. Schumann, R. Bährmann, \& A. Stark, Checkliste der Dipteren Deutschlands. Studia dipterologica Supplement 2: $354 \mathrm{pp}$.

OZEROV, A.L., 1989 - Flies of the families Sepsidae and Piophilidae (Diptera) of the Zejskij state nature preserve. Entomologitsheskoe obozrenie, 68 (4): 839-849.

OZEROV, A.L., 1991 - Review of the subgenus Platytoxopoda (Diptera, Sepsidae: Toxopodinae). Byulleten' Moskovskogo obshchestva ispytateley prirody, 96 (3): 48-53.

OZEROV, A.L., 1999 - Studies of Afrotropical Sepsidae (Diptera). II. A revision of the genus Meroplius Rondani. An International Journal of Dipterological Research, 10 (2): 81-96.

OZEROV, A.L., 2005 - World catalogue of the family Sepsidae (Insecta: Diptera) Zoologicheskie issledovania (Zoological Studies), 8: 1-74.

PONT, A.C., R. MEIER, 2002 - The Sepsidae (Diptera) of Europe (Fauna Entomologica Scandinavica). Brill, 198 pp.

SUH, S.J., Y.J. KWON, 1994 - Classification of the family Sepsidae from Korea (Diptera: Acalyptratae). Insecta Koreana 11: 58-63.

ZUSKA, J., M. BARTÁK, 1997 - Sepsidae. Pp. 74-75. In: Chvála, M.: Check list of Diptera (Insecta) of the Czech and Slovak Republics. 'Karolinum', Charles University Press, Prague, 130 pp.

*** http://www.codoncode.com

*** http://www.ncbi.nlm.nih.gov

Received: January 8, 2015

Accepted: February 26, 2015
Lavinia Iancu

"Grigore Antipa" National Museum of Natural History Şos. Kiseleff 1, 011341 Bucharest 1, Romania

e-mail: lavinia.paul@antipa.ro

Cristina Purcărea

Institute of Biology Bucharest, 296

Splaiul Independentei, Bucharest 060031, Romania

e-mail: cristina.purcarea@ibiol.ro 